\title{
Agents of Patriarchy Teach Gender
}

\author{
Rachel Sharaby \\ Department of Sociology, Ashkelon Academic College, Ashkelon, Israel \\ Email: rsharaby@gmail.com
}

How to cite this paper: Sharaby, R. (2019).

Agents of Patriarchy Teach Gender. Advances in Anthropology, 9, 13-31.

https://doi.org/10.4236/aa.2019.91002

Received: November 14, 2018

Accepted: January 8, 2019

Published: January 11, 2019

Copyright $\odot 2019$ by author(s) and Scientific Research Publishing Inc. This work is licensed under the Creative Commons Attribution International License (CC BY 4.0).

http://creativecommons.org/licenses/by/4.0/

\begin{abstract}
This article discusses veteran instructors who were employed by the absorbing establishment as instructors for women immigrants from Yemen who settled in moshav-type cooperative settlements in Israel. The findings indicate that the instruction messages in the first stage after the Yemenite immigrants settled on the land included a blurring of gender. However, differential instruction was created when the permanent homes were constructed: male instructors taught the men the hard physical labor, and female instructors taught the women their roles within the domestic sphere. The instruction system recruited to the new moshav-type cooperative settlements thus perpetuated the gender division of labor and used an effective "tool" for transmitting the patriarchic messages of the absorbing establishment.
\end{abstract}

\section{Keywords}

Yemenites, Patriarchy, Life Stories, Women Immigrants, Gender Division of Labor

\section{Introduction: Women Bound to the Home}

In its early days, literature on women's anthropology claimed a universal existence of patriarchy, and many researchers tried to develop theories that would explain this fact. According to de Beauvoir (2001 [1949]), the belief in their biological advantage enabled men to treat women as weak and passive biological entities, who are fit only for having children, caring for them and managing the household. Ortner (1974) also proposed an explanation according to which general social perceptions position women in a category that is closer to nature than to culture, which is connected to the men (see also Sanday, 1981).

Millett (2000 [1969]); Harpaz (2017: p. 14) proposed a different approach. She claimed that gender inequality does not stem from the man's physical advantage, but is rather a result of social structuration based on culture-dependent perceptions. According to Millett, the "role" is determined according to a sexual cate- 
gory: the woman is intended to care for the home and the children and the man is intended for roles in the public sphere. Rosaldo (1974) also employed a structural-social approach and stated that the roots of feminine inferiority are embedded in the seclusion of women from participation in the public sphere, which is intended to satisfy economic and political needs (see also Elshtain, 1981; Lips, 1988).

Izraeli (1999: p. 179) claimed that the woman is defined as a person who is tied to the home, as a member of the motherly sex, even if she lives alone and has no children. As such, she is perceived as obtaining satisfaction from the doing, from servicing the other and indirectly from the achievements of her spouse and her children. Other researchers stressed the relation between women and domesticity. They claimed that the feminine connection to the private sphere leads to their being perceived as having proven abilities in the field of affording help, cultivation and love and that their responsibility is to turn the home into a safe haven for their husbands and children (Fletcher, 1999: p. 21-19; Herzog, 1994). Gilligan (2012) assumed that men and women develop different worldviews regarding the relations created between the individual and the environment and among people. Moral judgment, which is based on the crystallized worldviews, reflects the uniqueness of each gender. Women develop a perception of responsibility, sensitivity and caring for the other and his needs, whereas men define the right to self-fulfillment and respecting the rights of others as a moral value.

The changes in gender norms that occurred in the $20^{\text {th }}$ century, and which undermined the traditional gender norms, did not lead to fundamental changes in the division of labor (Fogiel-Bijaoui \& Sharaby, 2017). Price (2002) presented the Western perception according to which the woman is not only ascribed to the home, but rather is perceived as its creator. The feminine experience is a domestic experience and concomitantly, the domestic experience is feminine. Ochs (1999), as well as Sered (1994), continued the claim regarding the woman's domestic identity and connected it also to religious life. These researchers claimed that men's restriction of women to the domestic sphere stems from their fear of women's ambivalence (Irigaray, 1985; Rosaldo \& Lamphere, 1974).

In spite of the claims of the above-mentioned theoreticians, according to which restriction of women is a product of masculine dominance, women were often appointed to supervise women's restriction to their homes. The supervising women are often members of the patriarchal man's family (Abu Lughod, 1993). However, there are cases where it is mothers and grandmothers of the young women who supervise her body and soul (Wolf, 1985). In both cases, these are women who were appointed by men to supervise the young women out of a belief that women are more familiar with the gender role and can more easily influence other women (see also Stoller-Lis, 2004).

Boddy (1989) presented a feminine perception of the need to adapt themselves, their body and their daughters to the masculine demands as a way of explaining feminine willingness to fulfill roles of supervision over other women. 
Abu Lughod (1993) added the feminine commitment to the family's men as contributing to their agreement to this supervision. These two scholars present the voices of women who supervise themselves when explaining the willingness to do what men say, and in both cases the women present personal, religious or feminine advantages for the supervising women.

According to the scientific literature, it is women who were in many cases appointed to supervise and influence women in fulfilling their domestic role. These scholars stressed the feminine commitment to the patriarchic social structure as a motive for their behavior (Abu Lughod, 1993; Wolf, 1985). Voluntary women's organizations which have existed since the late 1990s around the Western world, channel women to domestic activities and thus preserve the patriarchal gendered division of labor, out of a belief in feminine empowerment (Macleod, 1998: p. 9-29; Ogden, 1986: p. 167). This feminine activity acts to emphasize domestic functions among women who receive this instruction (Atzmon, 2001: p. 136; Hyman, 1995: p. 31).

The unique education for women is compatible with Chodorow's (1978) claim, according to which women, as mothers and educators, afford a different education to boys and girls. This education leads, in the end, to what she calls "replication of the mothers", i.e. the girls' perception of their gender role as inferior, contrary to the boys' perception of their active gender role. Friedman (2007) criticized Chodorow's claim and argued that this claim accuses the mothers of perpetuating the non-egalitarian gender relations.

In situations of immigration, women from the absorbing society are involved in instructing the new women immigrants. Here too, instruction compatible with the masculine messages and authority can be seen, where in practice the female instructors view themselves as supporting and empowering women. Furthermore, gender messages with cultural aspects are included in the instruction of the women immigrants. The research literature shows that the main fields of involvement of instructors among women immigrants focus on domestic fields: caring for children, preventive medicine, impartation of hygiene and parenting habits (Emmerich, 1997: p. 393-409; Rozin, 2005).

\section{Historical Background: Instructing Immigrants in Israel}

Under Western influence, women's organization involved in shaping the Israeliness of other women operated in Israeli society, even before the establishment of the State. These organizations were also involved in activity intended to advance women's political and social status. However, their main activities were in classic "feminine" domains: impartation of knowledge in the field of caring for the children and the family, cooking and cultivation of the home (Bernstein, 1987; Herzog, 1994).

Waves of mass immigration arrived in Israel after the War of Independence and the establishment of the State of Israel in 1948, and moshav-type cooperative settlements (moshav ovdim) served as a major mechanism for their absorp- 
tion. According to a report of the Moshavim Movement, 271 moshav-type cooperative settlements were founded for immigrants in the 1950s. These were populated mainly by immigrants from Asia and Africa (Keinan, 2004: p. 128). A high percentage of immigrants from Yemen relative to their number turned to the agricultural settlements, and they founded about 50 villages (Zandani, 2004: p. 43, 221).

The State of Israel afforded priority to the development of the rural areas, since they were intended to serve economic-security needs (Keinan, 2004: p. 114). Another goal was ideological. The state leadership regarded the inclusion of immigrants in the agricultural settlement as an important path on their way to becoming Israelis and "pioneers", in the image of the veteran members of the moshav-type cooperative settlements. The moshav thus became a mechanism for the achievement of the "melting pot" policy. The immigrants were perceived as needing modernization and re-socialization, and were required to adopt the dominant Israeli culture (Lissak, 1987; Weingrod, 1996).

The leaders of the Moshavim Movement which was identified with the ruling "Workers' Party of the Land of Israel" (Mapai), complied with the request of the government, headed by David Ben-Gurion, and undertook the absorption of immigrants within the movement's framework. Their position was explained by national and social considerations and the belief that they could generate a cultural and social change among the immigrants. Political motives, some of them internal, also influenced the heads of the Moshavim Movement: they hoped to recruit the immigrants and strengthen the power of the party (Hacohen, 1994: p. 139).

Dozens of veteran moshav members answered the call of the Moshavim Movement and went to the immigrant camps and the new moshav-type cooperative settlements in order to instruct the immigrants and help in their absorption (Sharaby, 2005; Weingrod, 1966). The instructors of the first immigration wave went to the moshav-type settlements alone, without their families. However, the instructors of the second immigration wave of the mid 1950s were required to live in these settlements with their families, in order to identify with the settlers. At this stage, cooperation between all members of the team that arrived at the moshav increased: the social instructor, the agricultural instructor, the nurse, the teacher and the kindergarten teacher. It was understood that a team must come to this settlement, and not a single instructor, who with combined forces would storm the target and conquer it (Hacohen, 1994: p. 140).

The instruction was intended to generate a social and cultural change among the immigrants in the attitude that was named "the guardianship strategy" (Lissak, 1999: p. 134-136). The male instructors focused on instructing the men on issues of management, finance and agricultural work. The women instructors were told to instruct the women immigrants on issues of managing the household, caring for the children, preventive medicine and impartation of hygiene and aesthetic habits. The female instructors acted out of a sense of ideological mission, and regarded the instruction as sacred work (Rozin, 2005; Stoller-Lis, 
2004).

\section{The Gender Conflict in the Moshav-Type Cooperative Settlements}

This article will focus on the work of the female instructors in the moshav-type cooperative settlements of immigrants from Yemen in the first decade after the establishment of the State of Israel, an issue that has not been illuminated to date. A rigid gender division of labor between the "private sphere" and the "public sphere" existed in the traditional society from which the Yemenite women immigrated. The women's roles were limited to giving birth, educating the children and managing the household, whereas the men fulfilled the public and religious roles, and controlled the power, authority and ownership of property (Eraqi-Klorman, 2004: p. 207-208).

According to Bott (1957), the tighter the relations between the individuals who compose the family network (dense network), the greater is the extent of separation between the husband's and the wife's roles. Each of them receives support, separately, from their network, and their demands of their spouse will thus be relatively small. Similarly to Bott's model, the extended family in Yemen enabled cooperation in the economic field between the men, and they could waive the women's cooperation in this domain. The women could therefore be restricted to housework (Eraqi-Klorman, 2004: p. 207-208).

The women immigrants from Yemen arrived in Israel to the unique agricultural-social framework of the moshav-type cooperative settlement, whose ideology was contrary to the patriarchic family structure. One of the main principles of the moshav was the family farm (Yaffe, 1919: p. 13-14). Those who invented the idea of the moshav stressed the freedom of the nuclear family as an independent unit, where the wife is a full partner to work on the farm and is responsible for this work.

Since the family unit in the moshav comprised a basic social and economic unit, this obligated planning and designing the settlement, such that it enabled division of the land into the same number of independent units as the number of families who lived there. The lot on which the house was built fulfilled a dual role, so that the wife and children could participate in the farm work: it was a consumer center of the family and a productive center on whose area the farm buildings and the yard industries would be set up (the chicken coop, barn and vegetable garden). More distant plots served as orchards and for cultivation of crops.

The economic reality in the moshav in Israel to a great extent caused the break-up of the extended family that emigrated from the Islamic countries, and led to the establishment of independent nuclear families. In this new social and economic organization, each family unit was dependent on a single adult male. The wife therefore served as the main source for helping the man's economic activities, and was crucial as a partner during the first years of founding the farm 
and the moshav (Sharaby \& Kedem-Hadad, 2017). The changes in the traditional division of roles are compatible with Bott's theoretical model.

However, it appears that while the gender division in the moshav was blurred to a great extent in the economic field, other norms pertaining to gender roles remained valid also in the new reality, since they were deeply rooted among both men and women. They continued to adhere to traditional values, and did not try to change the patriarchal structure that afforded the man exclusivity in representing the family and in interactions outside the family (Sharaby \& Kedem-Hadad, 2017).

This introductory discussion indicates that the early period of establishment of the moshav-type cooperative settlements in the 1950s is particularly interesting in terms of gender. The inclusion of female instructors in the settlement plan and their contact with the women immigrants raises a dual interest in this period. This article will examine the gender and cultural contents which the female instructors transmitted to the women settlers from Yemen, according to testimonies of women immigrants and female instructors. It will focus on the question of whether they gave the women immigrants tools for coping with the gap between the gender norms and whether they helped them increase their economic power in the family and in the community, and thus undermine the traditional division of labor.

\section{Methodology}

The research is based on diverse primary sources, most of which have not been exposed to date, since the voice of women from the Islamic countries were awarded only a marginal place in the historiographies of that period. I found a great treasure in archives and libraries, on which I performed content analysis: memoires of female instructors that were published in the past decade, as well as impressions of the experiences of the instructors, which they wrote over the course of their work with the immigrants, and appeared in the Tlamim journal of the Moshavim Movement and anthology collections published in the 1960s.

The research is also based on interviews held with women of the moshav-type cooperative settlements from 2001 to 2002, within the framework of the Yad Tabenkin Institute for Research on Spanish and Oriental Communities as well as interviews held within a project of documenting the Yemenite Jews of the Eele Betamar Association. Additional interviews were held in 2009-2010, some together with Naama Hadad-Kedem. I completed details by phone or by meeting with the interviewees, while writing this paper.

The field work included 25 semi-structured interviews with women who immigrated to Israel from Yemen in 1949. They immigrated as married women, aged $17-25$, and most were already mothers to one to three children. During the interviews, which were conducted in 2008-2009, they were in their seventies and eighties and were living in moshav-type cooperative settlements in the Jerusalem area. The interviews also included five female instructors, who were veteran members of moshav-type settlements and were still alive and could be inter- 
viewed. Thus, a total of 30 women were interviewed. The names that appear in the article are fictitious, in order to maintain their privacy.

The interviews produced the women's life stories, where they described their immigration and their move to the moshav in the first decade after the establishment of the State. The interviews were analyzed qualitatively, according to the analysis model proposed by Lieblich et al. (1998). This method tries to expose social phenomena, a historical period and a personal identity through the story. The life story is also told according to certain cultural patterns (Narayan \& Kenneth, 2001). It is therefore possible to understand the cultural contents that guide the women and the historic and social context that influenced the establishment of their identity via analysis of their life stories.

An inherent problem when using a method based mainly on late testimonies of women, which is typical for life story studies (Schely-Newman, 2002), is that older people tend to forget, idealize the past and accept events and conflicts they encountered. The stories of the women of the moshav-type cooperative settlements during the first years of the State can be regarded as an interesting case of “delayed narrative" (Rosen, 2005-2006: p. 195). For different reasons, these stories were not told at the time in broad circles or outside the immigrant communities, but only after many years. The contents and topics of their stories as told may therefore reflect not only the absorption experience but also processes and concepts they experienced up to the time they told their story (Tuval-Mashiach, 2000).

In spite of the presented dilemmas, it is impossible to ignore the importance of oral documentation. It sometimes completes missing or limited historical material in the official documentation. It also affords an authentic expression of the person's state of mind and the everyday occurrences that do not appear in formal documents. The stories of women in general, and of women immigrants from Islamic countries in particular, are even more important as a cultural text that binds personal and social meanings. It enables the women to sound their voice and to add other knowledge, that is free of the dominant ideology (Hill-Collins, 2000; Motzafi-Haller, 2001).

\section{Testimonies of the Women Immigrants: "The Instructors Taught Us Everything"}

\subsection{Joint Instruction for Women and Men}

The first steps of the new settlers were accompanied by instructors, who helped and instructed them in putting up their tents and in preparing the initial infrastructure of the moshav. The impression left by the interviewees is that during this initial period, where it was crucial to recruit all forces for founding the moshav, the instructors guided all immigrants in the physical tasks, without any distinction between men and women.

Mazal, from Moshav Mash'en, described: “There was nothing here, only thorns and thistles. No trees, nothing, no houses. We were thrown into the field 
and were told: Come on, start working now. And we started working-children, women, men. First we began by destroying the weeds and then we began to put up the tents ... The Yemenites did not despair. They worked hard, women, children and men" (Eele Betamar Project, disc 4, section 64). The stories of settling in the moshav-type cooperative settlements thus expose descriptions of great cooperation between men and women. The traditional gender role division was forgotten in light of the existential necessity, and the instructors contributed to this egalitarian situation.

After a few months of organizing, the instructors arranged work of stone removal, fencing and planting in the agricultural areas, mainly in the forests outside the moshav for the settlers, both men and women, in order to solve the immigrants' unemployment problem (Avdar, 2000: p. 221). Women told of the tiring walk to the work area and their hard work. For example, Hannah from Moshav Bitkha: "The women also worked in this in order to earn a living. For example, Yair's mother was nine-months pregnant with twins, and she continued to work in order to earn a livelihood for her children ... She went to work out in the field, physical labor, to bend, to plant seedlings, to hoe" (Sulami, 2011: p. 144).

About one year after settling on the land, the immigrants were moved to shacks, where they lived for about one year. The instructors organized the settlers in work inside the settlements: preparing the soil, destroying abandoned houses and laying water pipes. They taught the men to make bricks, and the men built the homes and the public buildings, under guidance of the instructors (Eele Betamar Project, disc 4, section 59A, disc 4, section 69A; Sulami, 2011: p. 146). At this stage of building the permanent homes, a gender division was already discernible, and only the men were instructed in the hard physical labor.

Upon completion of the building of the houses and their division by a lottery, the lands of the moshav were divided among the settlers. Each family received, in addition to the lot with the house that also included a chicken coop and a barn, a nearby plot for agricultural crops. Additional lands were allocated for orchards, for collective farming by members of the moshav. At this stage, men, women and children removed the stones from the plot to prepare it for cultivation. Saada from Moshav Eliakim told: "We carried stones in our hands, stones on our heads, a few women aborted children ... I was the first and aborted twice because of the work. We worked while pregnant. What could we do? I was giving birth to a girl, her head was smashed by stones in a basket on my belly" (Eele Betamar Project, disc 5, section 1).

\subsection{Gender Separation}

Most of the Yemenite Jews were not farmers in their country of origin, and therefore were helped by instructors in their farming. The instructors also supplied them with work tools, horses, mules, seeds and seedlings through loans from the Jewish Agency. The descriptions indicate that gender differentiation in the professional instruction became clearer at this stage, since the agricultural instructor taught the men how to care for the beasts of burden and trained 
mainly the men for the agricultural labor (Eele Betamar Project, disc 4, section 61A).

The women shared in the burden of working the land and marketing the agricultural produce. Tamar from Moshav Bitkha recalled: "We grew cabbage and onion. For picking, we received boxes and would carry them with the produce on our heads to the warehouse of the Tnuva Company, which was located in the center of the moshav, at a great distance" (Sulami, 2011: p. 129; see also descriptions on pp. 148-150). In families where the husband worked as an employee outside the moshav, the women carried the burden of the farm alone (Eele Betamar Project, disc 4, section 74A).

The settlers established a livestock farm in the home plot, with the help of loans. This included, at first, a cow or goat and fifty fowl. The instructors taught them the professional work necessary for caring for the animals, such as injecting and spraying them when they were ill. It should be noted that since the men worked mainly in hard physical labor in and out of the moshav, the women, with help from the children, carried the burden of work in the chicken coop and also helped the men care for the cows. Ora from Moshav Mash'en told of their responsibility for the livestock: "We did everything by hand. We milked by hand, we reaped with a sickle ... We would take the grass on our heads from the field to the cows. We also tended the chicken. We tried everything. I had to work in the field and raise children. The women worked hard. We would cook and do the laundry all night. The men also worked hard in the fields" (Eele Betamar Project, disc 4, section 64).

While the men were trained to roles in agricultural work, the women were trained for classical "feminine" roles: childcare and managing the household. This function was at first fulfilled by female soldiers who were sent to the moshav-type cooperative settlements. Interviewees told that they gathered, each time in a different woman's house, and the female instructors taught them how to cook. Zviya said: “They opened a grocery store, brought some things, beans, peas ... We did not know how to cook such a soup. A female soldier came and said, come, they began to teach us ... Cook peas, cook beans, there is no meat like there was in Yemen, don't dream, it is harsh here". The female soldiers also taught the women reading, writing and arithmetic (Eele Betamar Project, disc 4, section 74).

\subsection{Learning the Language}

After some time, female instructors who were veteran moshav members replaced the female soldiers. Malka from Moshav Naham told: "We had an instructor, she was a veteran, so she taught us how to cook, how to bake, how to make pickles, puree ... She taught us everything. This instructor would meet with us once a week. For five years, I think, every week, one day. This was the instruction, for all women from the settlements around Jerusalem, whoever wanted to come".

Some of the female settlers persisted in coming to the instruction lessons, but 
others did not attend them. One of them explained: "Learning in the evening, after an exhausting day that began with the first light, going out into the field and then caring for the chicken coop, the home and the children, where do you have strength [to learn]?" Another interviewee voiced similar things: "I began to learn and stopped, because of the work and the children, and they would begin (the studies) at seven in the evening, that is difficult, we have no strength".

Through an initiative of the Ministry of Education, the "Operation for Impartation of Language" was begun in 1955, and thousands of Ministry of Education and Israel Defense Forces teachers were recruited to teach in the moshav-type cooperative settlements. They taught Hebrew, as well as history, literature and acquaintance with the State of Israel (Sulami, 2011: p. 163-166). Many of the women, especially the younger ones, took on the challenge to learn, but in the interviews reported on difficulties they had at the time. Hannah from Moshav Tarum told: "At the beginning I did not go to the lessons, because I had children. The teacher said come learn. I said to her that she should come to my home. She came, took my hand and taught me to write" (Eele Betamar Project, disc 4, section 49A).

These and other things show the contribution of the female instructors to a change that took place in the right of the Yemenite women in Israel to learn to read and write, a right which they did not have in Yemen (Eraqi-Klorman, 2004: p. 207-208). However, the interviewees' descriptions did not include evidence that the female instructors encouraged them to exploit their essential economic partnership for increasing their power in the family and in the moshav community. This is because the instructors, just like the women they instructed, were still prisoners of traditional gender perceptions.

The interviewees voiced mainly esteem for the instructors who helped the settlers earn a living and exploit available products for domestic consumption. One of the women indicated: "I became so attached to them. They spoke nicely, helped those who needed help. When I parted with them my heart ached". Shoshana from Moshav Mash'en praised the female instructor: "Who cared for all the sick people and the women giving birth, everything. She was responsible here and did over and beyond her duty" (Eele Betamar Project, disc 4, section $74 \mathrm{~A})$. However, criticism of the instructors' negative attitude toward the immigrants was also voiced. Zviya from Moshav Ora said: "An instructor came, who was from Europe. He felt that he was superior, referred to the men as pitiable, stupid".

\section{Testimonies of the Female Instructors: "We Did What Needed to Be Done"}

\subsection{Volunteering for the Job}

In the interviews, the female instructors told that they and the male instructors came to the moshav-type cooperative settlements as volunteers, following the call of Prime Minister David Ben-Gurion to members of the veteran settlements, 
and that it was important to them to volunteer for a national goal. Noa from Kfar Yehoshua was sent to Moshav Aminadav. She said: "We did not ask questions. They called on us and we went. We came and knew that we must help. We were a generation that did things".

Ziporah from Moshav Nahalal, who was an instructor in Moshav Heletz, told: "There was a general assembly. When Ben-Gurion came and said: We must go and instruct the families ... We left the assembly and on the way talked amongst ourselves, how can we close our farms and go and instruct? The question was not a yes or no question. Only yes. On the way we planned how to carry this out". The ideological fervor is also apparent in the sayings of Rivka from Nahalal: "From the first moment I viewed my place as being among the volunteers. I regarded it a national obligation to contribute my part to the absorption of the mass immigration that came immediately after the establishment of the State. Indeed, when asked by the Moshavim Movement to go and be an instructor, I agreed with a willing heart" (Grinker, 1976: p. 130-131).

The female instructors testified that they and the male instructors were in their early twenties, and did not receive any training for the role of instructor. Yaffa from Kfar Yehoshua, who was an instructor in Moshav Aminadav, admitted: "We received training for two days ... From today's perspective, experienced instructors should have been sent." The instructors also did not receive any preparation on the immigrants' culture and therefore experienced a "culture shock" in their first encounter with them. For example, Noa recalled: "I did not understand. They spoke Hebrew with a Yemenite accent. There were only Yemenites. I saw that I did not understand the accent. They were all Yemenites. Harsh conditions, no water".

The female instructors reported on coping with the cultural-ideological gap also during the course of their work. Rachel told: "For me, this was something different, one of my first opportunities to understand cultural difference and respect it. As Israeli-born I saw the new immigrants, the difference was great, because in my youth the immigrants were from European countries, very different. This was an opportunity to face a cultural difference".

Ziporah expressed her frustration, in light of her difficulty in introducing the rules of a moshav to the immigrants and said: "Our moshav was one of only Yemenites, including men who had two wives. How can you begin to teach them the principles of the moshav, the cooperative life. We had to teach them to work, sell their produce and basic things in a concentrated manner. This was very difficult work emotionally. We had to begin everything from scratch. They did not understand".

Rivka, who is an enthusiastic missionary of the movement, well explained the source of the difficulty of the instructors: "The new settlement project found us, the veteran settlers, unprepared for the big change that took place in the settlement after the establishment of the State. We had decades of experience of working and building the villages, but we worked under different conditions and 
with different human material ... We had to invest a great amount of effort and to experience many disappointments, until the people adapted to conditions in this country and to farming methods of the moshav-type settlements" (Grinker, 1976: p. 137-139).

\subsection{Gender Messages}

The female instructors' lack of training was expressed in vagueness regarding their role. They therefore acted intuitively as women and learned their role through doing, as can be learned from Yaffa: "The female instructors did not have a clearly-defined role. They did what had to be done. An instructor from Jerusalem taught songs and dances, and we went to the homes ... The women received us very nicely. We sat, laughed and talked. We taught them to cook Israeli foods: pancakes, soup, meat patties ... The Yemenites cooked spicy soup with chicken and baked tasty pitas. They would bring me ... We went between the homes ... The conditions were harsh, with a baby and one on the way. Often we rode with them to the sick fund, because they did not know what to do, were not familiar ... The women had no awareness".

In the interview, Ziva described her work and her relations with the women: "I would go to the homes. I did not know how to cook. I would go to the kindergartens, settle matters at the sick fund, in the offices. There was no bus service to the moshav. The immigrants learned Hebrew, the women too. The Yemenite women were nice. I think that the women appreciated this. The relations were good. They always invited the instructors on the holidays, to weddings".

Ziporah told: "The attitude of the women immigrants was such that after two years we felt at home, and they opened their homes and their problems ... The fact that we lived in the moshav for two years did something. This gave us a right for involvement and gave them the feeling that we are with them". Rachel clarified: "In terms of that period, of the late 1950s, we dealt in what belongs to women's roles: raising children, cooking, hygiene, home visits, informal talks, mainly with women, but also with the men. We were strange creatures, different from the female immigrants, but I do not remember any tension on this background. I was always received nicely. We were given of what little food there was. The atmosphere was pleasant, with individual differences".

These descriptions of the female instructors clearly reflect their gender messages that delineated the women immigrants to their domestic roles and perpetuated the classical gender division of labor. The instructor Rachel indicated: "The division of labor was very traditional: the men worked in agriculture, the women worked at home and helped a little with agriculture. I do not remember any complaints by the women. There was general dissatisfaction. The immigrants underwent a very serious change. If there were conflicts between men and women, they did not come to us for help, and we did not interfere".

Other female instructors emphasized their involvement in the immigrants' family life, and took credit for changes that occurred in it. They regarded their 
work as instructors and particularly in the impartation of education to the female immigrants, as a major tool for the socialization process undergone by the women and their partners in the new social reality. Rivka said: "The work of the female instructors was sacred work and not just instruction. She succeeded in motivating the family to send the children to school, succeeded in bringing the mother to lessons and instruction gatherings in the village. These are also among the achievements we had during that decade" (Grinker, 1976: p. 142).

Sara proudly reviewed the efforts of the female instructors in the early 1960s and their achievements in the immigrants' settlements: "Members of the Moshavim Movement invested great effort in educating the woman, in particular the female immigrant from Islamic countries whose status was very low. For long generations they suffered from illiteracy, were secluded in the home and were subservient to the man who dominated everything. With time, important changes took place in the lifestyle and outlooks of the female members of the immigrants' settlements. The primitive habits became less common, the external appearance changed, order and cleanliness improved in caring for the family, groups for learning Hebrew were organized and they participated in field trips, conversations and committees for mutual help. Indeed, it was not easy to prove the importance of all these activities to a woman, and in particular to a man. However, frequent home visits, personal acquaintance and unending explanations reached the woman's recognition that she must acquire some education" (Kafri, 1962: p. 272-273).

\subsection{Political and Ethnocentric Messages}

Elka summarized with satisfaction: "Since the women immigrants came to Israel, we went quite a long way. They straightened their backs, renewed in their homeland and feel that they belong to the Moshavim Movement, and that there is someone to rely on. A woman born in Yemen, who never went to school, acquired her little knowledge with the help of Hebrew lessons under the auspices of the Ministry of Education, and participates in conventions of female members of the moshav-type cooperative settlements on different problems and events of the Movement and the nation. She is busy with her domestic chores and her farm, but this work does not stop her from taking time for general issues. The female members of the immigrant settlements are cared for by our movement. In addition to their absorption in the work life of an independent farm, the instruction helps their cultural development and the development of their movement consciousness" (Shohat, 1962: p. 274-275).

Thus, these instructors present not only gender achievements, but also political ones, i.e. recruitment of the female immigrants as members of the Moshavim Movement and the Mapai Party. Their sayings clearly reflect their sense of movement-political mission with which they set out to the moshav-type settlements, and their identification with the ideological cultural perceptions of the absorbing mechanism. These perceptions mean a "melting pot" policy, accord- 
ing to which the immigrants must adapt to modern Israeli society via a linear process.

Rachel clearly expressed these attitudes in the interview: "The role was a role of absorption, integration and Israelization. This is the model in which we live, and our role is to help them accept this model. Everyone's interpretation was according to his personality and values". She also told of the experience of one of the leaders of the female workers' movement (did not indicate who this was) in a visit to Moshav Eshtaol: "I walked around with her in the moshav. Eshtaol spreads over a hill. We went together to the kindergarten. The Yemenite children were playing and she said: When will the day come when the immigrants' children will dress like the Israeli children, in a white shirt and blue shorts?"

In spite of the optimistic description and the empathy toward the suffering of the settlers in the moshav, an attitude of patronization and stereotypic perceptions are also prominent in the sayings of some of the female instructors. For example, Ziva, who in the interview expressed her impression of the different immigrant groups which she instructed: "The Kurds were very primitive ... Care for the babies was amazing, primitive, babies slept in a kind of cradle, their entire body was wrapped, without any movement ... The Kurds loved to dance and sing. Another thing that astonished me that I did not know is the custom that when someone died a meal would be held for the mourners and the people coming to comfort them. For me this was something new, things I did not know. Compared to those who came from the distant mountains, the Yemenites are smarter, more developed ... We connected with them. When we would stay in the moshav for the Sabbath, and my husband loved to go to them ... The group of immigrants from North Africa were much more backward. The Moroccans were not easy and had complaints and claims".

\section{Conclusion}

This article discusses female instructors who are veteran immigrants employed by the absorbing establishment to instruct women immigrants from Yemen, and examines the gender and cultural contents they transmitted to the women. From these testimonies, it appears that during the first period after the Yemenite immigrants settled on the land, there was gender vagueness in the instruction messages, and men and women instructors taught both men and women. Since they were very poor and needed all the manpower they could get for founding their moshav and their farms, the settlers were, in my opinion, in a liminal state which Turner (1974) called "communitas". This is a situation characterized by temporary separation from the structure of a particular social system and removal of social divides. This explains the partnership between the sexes and the temporary disappearance of gender differences, which the instructors accompanied.

However, in the stage of building the permanent homes, when the settlers began to receive family "property" and the structure of the nuclear families began to clarify, the instructors created gender distinction in the subjects of the in- 
struction and its contents. Male instructors instructed the men in the physical construction work and in the professional jobs related to agriculture and livestock. In contradistinction, female instructors guided the women for roles in the domestic sphere, since they, like the women they instructed, were still captives of traditional gender attitudes.

One of the fields that could have served as a lever for increasing the power of the women immigrants from Yemen and for generating a fundamental change in their status was education. Feminist thinking stresses the connection between knowledge and feminine empowerment (Connell, 1987; Hooks, 1984). According to Hill-Collins (2000), acquisition of knowledge contributes to understanding the social-cultural reality in which the woman is found and which influences her life. However, the knowledge which the female instructors imparted to the women immigrants from Yemen in the moshav-type cooperative settlements was not translated into empowerment or into undermining the gender division of labor.

I also found no evidence that the female instructors encouraged the women to exploit their economic partnership for increasing their power in the family and in the moshav community. The women were therefore cut off from the public sphere and were secluded from the decision-making junctions, as can be inferred from Sara's sayings: "Haim was head of the committee ... Even today I do not know the role of the members of the committee and the head of the committee. I don't know how they were elected, I never went to a meeting" (Eele Betamar Project, disc 4, section 61A).

Shedra from Moshav Ahihud complained: "I would not exaggerate if I said that she is banned from male society and cannot even participate in the general assembly that takes place in the village from time to time. With us, the female member does not hold any public roles and is not elected to the moshav management. This is because of a prejudice of immigrants from Yemen, that the woman's rank is lower and she should not participate in public life" (Manzur, 1962: p. 263).

The differential instruction and the delineation of the women to their domestic roles perpetuated the gender division of labor that existed also in the veteran moshav-type cooperative settlements. This inequality was created in spite of the socialist ideology that served as the basis for its principles (Fogiel-Bijaoui \& Sharaby, 2017). The female instructors who were recruited for the moshav thus served as an effective tool for transmitting the patriarchic messages of the absorbing establishment.

From the cultural aspect, the female instructors clearly exhibited the sense of their movement's political mission in their testimonies, and their identification with the ideological perceptions of the absorbing mechanism. The lack of training for their role, as well as the cultural gap, created a culture shock in their first encounter with the immigrants. During the course of their work they also expressed frustration in light of the immigrants' difficulties in internalizing the 
moshav values, and sometimes expressed a paternalistic attitude toward the immigrants and their culture.

\section{Contribution of the Research}

This article may help policy makers involved in immigrant absorption to pay attention to attitudes of patriarchy among immigrants and even among agents of the establishment. In today's multicultural society, attention should be paid to the empowerment of women who arrive from patriarchic societies. Another contribution of this research is the illumination of the fact that the instructors (both male and female) were not informed on the culture and practices of the immigrants from Yemen. This is an aspect that policy makers must take into account in the absorption of immigrants in general. Furthermore, the fact that the female instructors were "asked" to leave their own homes, families, farms, to help in the absorption of the Yemenite immigrants was unfair, to say the least, since they did this voluntarily, without payment. Policy makers should take this into account, and allocate funds for instruction.

\section{Limitation of the Research}

As mentioned in the Methodology section, an inherent problem when using a method based mainly on late testimonies of women, is that older people tend to forget, idealize the past and accept events and conflicts they encountered. The stories of the women of the moshav-type cooperative settlements can be regarded as a case of "delayed narrative" (Rosen, 2005-2006: p. 195). The contents and topics of their stories as told may therefore reflect not only the absorption experience but also processes and concepts they experienced up to the time they told their story.

\section{Acknowledgements}

This article was supported by the Research Committee of the Ashkelon Academic College, Israel.

\section{Conflicts of Interest}

The author declares no conflicts of interest regarding the publication of this paper.

\section{References}

Abu Lughod, L. (1993). Writing Women's Worlds. Berkeley: University of California Press.

Atzmon, Y. (2001). History of Taking Responsibility. In Y. Atzmon (Ed.), Will You Hear My Voice? Representations of Women in Israeli Culture (pp. 134-152). Tel Aviv: Hakibbutz Hameuchad and Van Leer Institute (Hebrew).

Avdar, C. (2000). Placed and Formed-From the Village in Yemen to the Moshav in Israel. Ora: Self-publication (Hebrew).

Bernstein, D. (1987). A Woman in Israel: The Aspiration to Equality during the Settlement Period. Tel Aviv: Hakibbutz Hameuchad (Hebrew). 
Boddy, J. (1989). Wombs and Alien Spirits, Women, Men, and the Zar Cult in Northern Sudan. Madison, WI: The University of Wisconsin Press.

Bott, E. (1957). Family and Social Network. London: Tavistock.

Chodorow, N. (1978). The Reproduction of Mothering: Psychoanalysis and the Sociology of Gender. Berkeley: University of California Press.

Connell, R. W. (1987). Gender and Power: Society, the Person and Sexual Politics. Stanford: Stanford University Press.

De Beauvoir, S. (2001 [1949]). The Second Sex (Vol. A). Tel Aviv: Babel (Hebrew).

Elshtain, J. B. (1981). Public Man, Private Woman (pp. 298-353). Princeton, NJ: Princeton University Press.

Emmerich, L. E. (1997). American Indian Women Assimilation Policy and Scientific Motherhood, 1912-1918. In E. Jameson \& S. Armitage (Eds.), Writing the Range: Race Class and Culture, in the Women's West (pp. 393-409). Norman: University of Oklahoma Press.

Eraqi-Klorman, B.-Z. (2004). The Yemenite Jews (Vol. 2). Tel Aviv: The Open University (Hebrew).

Fletcher. A. (1999). Gender, Sex, and Subordination in England; 1500-1800. Yale: Yale University Press.

Fogiel-Bijaoui, S., \& Sharaby, R. (2017). Introduction: Reconstructing the Private and the Public Spheres. In S. Fogiel-Bijaoui \& R. Sharaby (Eds.), Dynamics of Gender Borders: Women in Israel's Cooperative Settlements (pp. 1-15). Berlin: Walter de Gruyter $\mathrm{GmbH}$ and Jerusalem: Magnes Press.

Friedman, A. (2007). Motherhood in Light of Theory. In N. Yanai, T. Elor, O. Lubin, \& H. Nave (Eds.), Methods in Feminist Thinking: Introduction to Gender Studies (pp. 25-45). Ramat-Gan: The Open University (Hebrew).

Gilligan, C. (2012). Joining the Resistance. Cambridge: Polity Press.

Grinker, R. (1976). Paths of the Daughter of the Rural Village. Tel Aviv: Self-Publication with Help from the Moshavim Movement. (In Hebrew)

Hacohen, D. (1994). Immigrants in Turmoil: Mass Immigration to Israel and Its Absorption in Israel 1948-1953. Jerusalem: Yad Ben Zvi Institute (In Hebrew)

Harpaz, D. (2017). “Woman-Alone” in the Workers' Moshavim during the Mandate Period 1922-1948. MA Thesis, Raanana: The Open University. (In Hebrew)

Herzog, H. (1994). Realistic Women-Women in Israeli Local Politics. Jerusalem: The Jerusalem Institute for Israel Studies. (In Hebrew)

Hill-Collins, P. (2000). Black Feminist Thought-Knowledge; Consciousness and the Politics of Empowerment. New York, London: Routledge.

Hooks, B. (1984). Feminist Theory: From Margin to Center. Boston: South End Press.

Hyman, P. E. (1995). Gender and Assimilation in Modern Jewish History: The Roles and Representations of Women. Seattle, WA and London: University of Washington Press.

Irigaray, L. (1985 [1977]). This Sex Which Is Not One (Trans., Porter, C.). New York: Cornell University Press.

Izraeli, D. N. (1999). Gendering of the Work Place. In D. Izraeli et al. (Eds.), Sex Gender and Politics: Women in Israel (pp. 167-215). Tel Aviv: Hakibbutz Hameuchad. (In Hebrew)

Kafri, S. (1962). Problems of Society in the Immigrant Moshav. In Y. Margalit (Ed.), House in the Moshav, Female Members Talk (pp. 271-274). Tel Aviv: Tarbut Vechi- 
nuch. (In Hebrew)

Keinan, O. (2004). Kibbutzim to Moshavim: Two Methods for Immigration Absorption in the First Decade of the State of Israel. Katedra, 112, 113-136. (In Hebrew)

Lieblich, A., Tuval Mashiach, R., \& Zilber, T. (1998). Narrative Research: Reading, Analysis, Interpretation. London: Sage. https://doi.org/10.4135/9781412985253

Lips, H. (1988). Sex and Gender. Mayfield.

Lissak, M. (1987). Immigrants' Images: Stereotypes and Stigmatization during the Period of the Mass Immigration of the 1950s. Katedra, 43, 125-144. (In Hebrew)

Lissak, M. (1999). The Mass Immigration in the 1950s: The Failure of the Melting Pot. Jerusalem: Bialik Institute. (In Hebrew)

Macleod, D. I. (1998). The Age of the Child, Children in America 1890-1920. New York: Twayne.

Manzur, H. (1962). Society in the New Moshav. In Y. Margalit (Ed.), House in the Moshav, Female Members Talk (p. 263). Tel Aviv: Tarbut Vechinuch. (In Hebrew)

Millett, K. (2000 [1969]). Sexual Politics. Urbana and Chicago: University of Illinois.

Motzafi-Haller, P. (2001). Scholarship, Identity and Power: Mizrahi Women in Israel. Signs, 26, 697-734. https://doi.org/10.1086/495626

Narayan, K. N., \& Kenneth, G. (2001). Personal and Folk Narratives as Cultural Representation. In J. Gubrium, \& J. Holstein (Eds.), Handbook of Interview Research Context and Method (pp. 815-832). London and New Delhi: Sage.

Ochs, V. L. (1999). What Makes a Jewish Home Jewish? Cross Currents, 49, 491-503.

Ogden, A. S. (1986). The Great American Housewife, from Helpmate to Wage Earner 1776-1986. Westport: Greenwood Press.

Ortner, S. B. (1974). Is Female to Male as Nature is to Culture? In M. Rosaldo, \& L. Lamphere (Eds.), Women, Culture and Society (pp. 67-88). Stanford, CA: Stanford University Press.

Price, J. M. (2002). The Apotheosis of Home and the Maintenance of Spaces of Violence. Hypatia, 17, 39-70. https://doi.org/10.1111/j.1527-2001.2002.tb01073.x

Rosaldo, M. Z., \& Lamphere, L. (1974). Introduction. In M. Z. Rosaldo, \& L. Lamphere (Eds.), Women, Culture and Society (pp. 1-17). Palo Alto: Stanford University Press.

Rosaldo, M. Z. (1974). Women, Culture, and Society: A Theoretical Overview. In M. Rosaldo, \& L. Lamphere (Eds.), Women, Culture and Society (pp. 17-42). Stanford, CA: Stanford University Press.

Rosen, I. (2005-2006). Construction and Structuration in the Stories of Immigrants and Their Children in the South of Israel. Jerusalem Studies in Jewish Folklore, 24-25, 195-220. (In Hebrew)

Rozin, O. (2005). Woman Absorbing Women. The Role of Veteran Women in the Absorption of the Mass Immigration in the 1950s, History and Theory. In A. Barel, D. Gutwein, \& T. Friling (Eds.), Society and Economy in Israel (Vol. 2, pp. 645-670). Jerusalem and Sde Boker: Yad Ben Zvi Institute and Ben Gurion Institute. (In Hebrew)

Sanday, P. R. (1981). Female Power and Male Dominance. Cambridge: Cambridge University Press.

Schely-Newman, E. (2002). Our Lives Are but Stories: Narratives of Tunisian-Israeli Women. Detroit: Wayne State University Press.

Sered, S. S. (1994). Priestess, Mother, Sacred Sister: Religions Dominated by Women. New York: Oxford University Press. 
Sharaby, R., \& Kedem-Hadad, N. (2017). Change and Transcription of Gender Roles in Moshavim of Immigrants from Islamic Countries. In: S. Fogiel-Bijaoui, \& R. Sharaby (Eds.), Dynamics of Gender Borders: Women in Israel's Cooperative Settlements (pp. 181-202). Berlin: Walter de Gruyter GmbH and Jerusalem: Magnes Press.

Sharaby, R. (2005). Hybrid Negotiation between Absorbers and Absorbed in the Workers' Settlement. Israeli Sociology, 6, 389-420. (In Hebrew)

Shohat, E. (1962). They Stood Tall. In Y. Margalit (Ed.), House in the Moshav, Female Members Talk (pp. 274-275). Tel Aviv: Tarbut Vechinuch. (In Hebrew)

Stoller-Lis, S. (2004). Instruction and Promotion of Health in Multicultural Societies: The Case of the Mass Immigration to Israel, 1949-1956. PhD Thesis, Beer Sheva: Ben Gurion University. (In Hebrew)

Sulami, T. (2011). Moshav Bitkha. Tel Aviv: Eele Betamar Publisher and the Moshav Bitkha Committee. (In Hebrew)

Turner, V. (1974). Dramas, Fields and Metaphors. Ithaca and London: Cornell University Press.

Tuval-Mashiach, R. (2000). Identity Gender and Status in the Life Stories of Women and Men in Israel. PhD Thesis, Ramat-Gan: Bar-Ilan University. (In Hebrew)

Weingrod, A. (1966). Reluctant Pioneers. Washington DC and London: Kennikat Press.

Wolf, M. (1985). Revolution Postponed: Women in Contemporary China. Stanford, CA: Stanford University Press.

Yaffe, E. (1919). Establishing the Cooperative Settlements. Jaffa: The Central Committee of the Young Laborer's Party. (In Hebrew)

Zandani, G. (2004). The Rural Settlement of Immigrants from Yemen in 1949-1967: Settlement and Social Aspects. PhD Thesis, Haifa: Haifa University. (In Hebrew) 